\title{
The death of plant cells: from proteases to field applications
}

\author{
S Stael, MK Nowack, F Van Breusegem, M Valls and NS Coll \\ Cell Death and Differentiation (2014) 21, 1984; doi:10.1038/cdd.2014.160
}

Correction to: Cell Death and Differentiation (2014) 21, 1178-1179; doi:10.1038/cdd.2013.190; published online 10 January 2014

Since the publication of this article the authors have noticed an error in the list of author names. F Breusegem should be $\mathrm{F}$ Van Breusegem. The correct list is shown above. There is also an error in the sentence contained within the second paragraph of text under the heading 'The future of plant PCD research'.

The sentence has been amended as shown below:

Apoptosis is an event found mainly in animals, a minority of the biological diversity on the planet.

The authors would like to apologize for any inconvenience caused.

\section{RIG-I-like helicases induce immunogenic cell death of pancreatic cancer cells and sensitize tumors toward killing by $\mathrm{CD}^{+} \mathrm{T}$ cells}

\author{
P Duewell ${ }^{1,2}$, A Steger ${ }^{1}$, H Lohr ${ }^{1}$, H Bourhis ${ }^{1}$, H Hoelz $^{1}$, SV Kirchleitner ${ }^{1}$, MR Stieg ${ }^{1}$, S Grassmann ${ }^{1}$, S Kobold ${ }^{1}$, JT Siveke ${ }^{3}$, \\ $S$ Endres ${ }^{1}$ and $M$ Schnurr ${ }^{*}, 1,2$ \\ Cell Death and Differentiation (2014) 21, 1984; doi:10.1038/cdd.2014.161
}

Correction to: Cell Death and Differentiation (2014) 21; 1825-1837; doi:10.1038/cdd.2014.96; published online 11 July 2014

Since the publication of this paper the authors have noticed an error in the addresses for affiliation 3 and the corresponding author.
This has now been rectified and the corrected article appears in this issue together with this corrigendum.

The authors would like to apologize for any inconvenience caused.

${ }^{1}$ Abteilung für Klinische Pharmakologie and Center for Integrated Protein Science Munich (CIPS M), Medizinische Klinik und Poliklinik IV, Klinikum der Universität München, Ziemssenstrasse 1, München, Germany; ${ }^{2}$ Medizinische Klinik und Poliklinik IV, Klinikum der Universität München, Ziemssenstrasse 1, München, Germany and ${ }^{3}$ Medizinische Klinik, Klinikum rechts der Isar, Technische Universität München, Ismaningerstrasse 22, München, Germany

${ }^{*}$ Corresponding author: M Schnurr, Abteilung für Klinische Pharmakologie, Klinikum der Universität München, Ziemssenstrasse 1, 80336 München, Germany.

Tel: +49 895160 5300; Fax: +49 895160 7300; E-mail: max.schnurr@med.uni-muenchen.de 